\title{
How does Unified Theory of Acceptance and Use of Technology (UTAUT) Work on Adopting Financial Technology (FinTech) by MSMEs?
}

Yohan Wismantoro $^{1 凶}$, MG Westri Kekalih Susilowati ${ }^{2}$

1 Department of Management, Faculty of Economics and Business, Universitas Dian Nuswantoro, Semarang, Indonesia

2 Department of Management, Faculty of Economics and Business, Soegijapranata Catholic University, Semarang, Indonesia

\section{Article Information}

\section{Article history:}

Accepted: April 2021

Approved: July 2021

Published: September 2021

\section{Keywords:}

FinTech

MSMEs

Digitalization

UTAUT

Inclusive

\begin{abstract}
Micro Small and Medium Enterprises (MSMEs) have a very significant role in the economy, can even be said to be the backbone of the economy. However, MSMEs are precisely the sector hardest hit by the Covid-19 pandemic. Digitalization creates new opportunities for MSMEs in the pandemic. FinTech, one of the implementations of digitalization should be pursued to be used by MSMEs. Using path analysis processed using Partial Least Square (PLS), this research aims to identify how Unified Theory of Acceptance and Use of Technology (UTAUT) works on Adopting FinTech by MSMEs. The Outer Model and Inner Model reflect that the model work. The outer loading value of $\geq 0.7$, AVE value $\geq$ of 0.5, Cronbach's Alpha $\geq$ 0,70 , a correlation value $\geq$ of 0.50; and Composite Reliability $\geq 0.6$, and $R$ Square 0.716 reflect it. However, regarding the factors that influence intention to use, it is different from previous research that became a reference. There are only four hypotheses proven. Those are Context had a significant positive effect on Perceived Ease of Use and Perceived Usefulness, and Perceived Ease of Use and Perceived Usefulness had a significant positive effect on the intention to use fintech.
\end{abstract}

How to Cite: Wismantoro, Y., \& Susilowati, M. (2021). How does Unified Theory of Acceptance and Use of Technology (UTAUT) Work on Adopting Financial Technology (FinTech) by MSMEs?. Jurnal Penelitian Ekonomi dan Bisnis, 6(2), 90-99. doi:https://doi.org/10.33633/jpeb.v6i2.4826

${ }^{\square}$ correspondence address:

Fakultas Ekonomi dan Bisnis, Universitas Dian Nuswantoro, Jalan Nakula 1 nomor 5-11, Pendrikan Kidul, Semarang

E-mail: yohan.wismantoro@dsn.dinus.ac.id
2442-5028 (print) 2460-4291

DOI: $10.33633 /$ jpeb.v6i2.4826 


\section{INTRODUCTION}

Micro Small and Medium Enterprises (MSMEs) have a very significant role in the economy, can even be said to be the backbone of the economy. With a small business scale based on local consumers, MSMEs products are always needed by the community. In addition, MSMEs are not dependent on the capital market and have proven to have high durability in crises. However, MSMEs are precisely the sector hardest hit by the Covid-19 pandemic. This condition occurs because the MSMEs sector is dominated by informal business units that require conducting business outside the home. The era of industrial revolution 4.0 marked by digitalization, automation, the internet of things (IoT), and artificial intelligence create new opportunities for MSMEs. The outbreak of covid 19 seems to be the trigger for the faster era of MSMEs digitization.

Digital technology is a medium for MSMEs to survive the covid period and is expected to accelerate the development of MSMEs business after covid 19. It can minimize the barriers of conventional business practices. The digitalization of MSMEs includes the performance of MSMEs that can survive or even grow during the pandemic and supports the creation of a sustainable and inclusive economy. The MSME digitization is reflected in the involvement of the poor in the expanded upstream to the downstream industrial supply chain. It means the digitization of MSMEs will contribute greatly to poverty alleviation efforts. One of the implementations of digitalization in business is the digitalization of payment methods, namely, non-cash payment methods use financial technology (FinTech). Based on this phenomenon, the acceleration of MSME digitization, especially in using Fintech needs to be pursued.

The problem is that introducing new technologies is not easy; it is very likely to be faced with resistance or lack of ability to adapt by the target user. Digitizing MSMEs requires hard effort because there are obstacles, including weak sustainable technology development, lack of adequate information, the inertia to change, weak e-commerce adaptation, and inefficient supply chains due to weak networks (Masurel, 2001). Therefore, digitalization behavior or adoption of digital technology in the development of its business and various factors that affect it need to be identified in depth. There are several approaches regarding the adoption of technology, including Unified Theory of Acceptance and Use of Technology (UTAUT), which is an extension of the Technology Acceptance Model /TAM (Shang Gaoa, John Krogstiea, and Keng Siau, 2017). This approach includes six variables consisting of three exogenous variables, namely Context, Personal InitiativesCharacteristics, and Trust. Four endogenous variables, namely Perceived Ease of Use and Perceived Usefulness, are a function of context and Intention to use, which is a function of Personal InitiativesCharacteristics, Trust Perceived Ease of Use and Perceived Usefulness.

It is important to understand the conditions of MSMEs' behavior intention and various factors that influence them to adopt FinTech in their business (implementing the FinTech of MSMEs). This research aims to draw alternative solutions to industrial problems, namely to overcome the problems of MSMEs as the sector most affected by the covid 19 pandemic and produce a formulating of MSMEs Fintech adoption intervention strategy. Thus, the results of this study will contribute to the economic efforts of financial inclusion as part of poverty alleviation efforts by improving MSMEs' competitiveness. In science and being a reference for similar activities, this research provides enrichment of the intervention model of digitalization behavioral intention.

\section{METHOD}

The object of this study is the adoption of the digitalization behavior intention of MSMEs on a perceptual basis with various factors that affect it conducted in the city of Semarang. This research includes as many as 56 MSMEs respondents in various types of products/businesses. The type of data used in this study is primary data in MSMEs perception of variable indicators developed in this study (Table 1). Data collection is done by survey method using questionnaire instrument. The primary data in this study is the perceptional data of selected indicators. The Likert Scale 1 - 5 (strongly disagree - strongly agree) is used to anticipate the perceptional data.

By its purpose, this research variable refers to the mobile services acceptance model, an extension of the technology acceptance model (TAM) by S. Gao, J. Krogstie, and P.A. Gransæther (2011). The model includes variables, i.e., Context, Personal Initiatives, and Characteristics, Trust, Perceived Ease of Use, Perceived Usefulness, Intention to Use. 
Table 1. Variables and Research Indicators

\begin{tabular}{|c|c|c|}
\hline Variable & Definition & Indicator \\
\hline Context (X1) & $\begin{array}{l}\text { Any information that can be used to } \\
\text { characterize the situation of the entity } \\
\text { (i.e., a person, place, or object) is } \\
\text { considered relevant to the interaction } \\
\text { between the user and the application, } \\
\text { including the user and the application } \\
\text { itself }\end{array}$ & 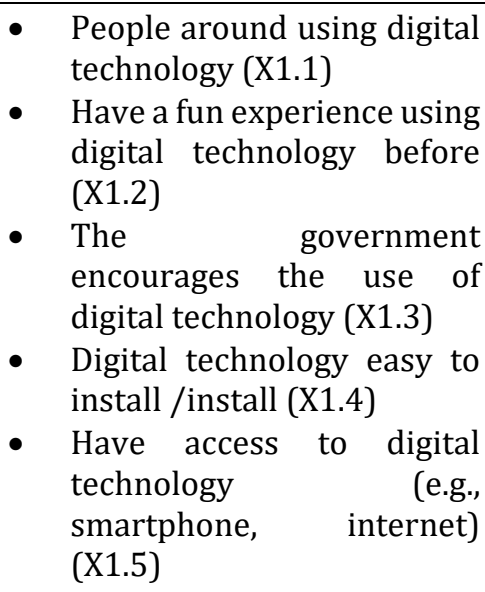 \\
\hline $\begin{array}{l}\text { Personal } \\
\text { Initiatives and } \\
\text { Characteristics } \\
(\mathrm{X} 2)\end{array}$ & $\begin{array}{l}\text { User willingness to experiment with } \\
\text { digital technology }\end{array}$ & 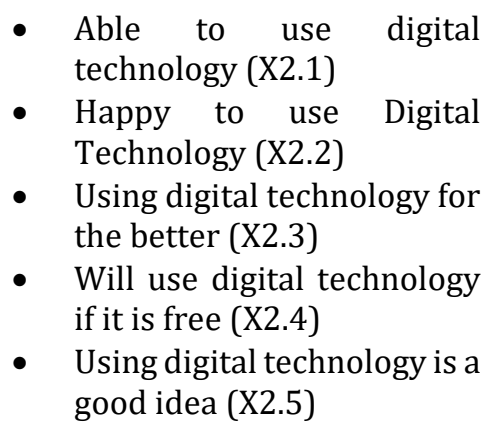 \\
\hline Trust (X3) & $\begin{array}{l}\text { The user's belief or belief that digital } \\
\text { technology is secure does not threaten } \\
\text { privacy. }\end{array}$ & $\begin{array}{l}\text { Will use digital technology if: } \\
\text { - } \quad \text { Know the functionality of } \\
\text { digital technology (X3.1) } \\
\text { - Widely known digital } \\
\text { technology provider (X3.2) } \\
\text { - } \text { digital technology protects } \\
\text { privacy (X3.3) } \\
\text { - Feeling confident in being } \\
\text { able to control digital } \\
\text { technology (X3.4) } \\
\text { Feel confident the data } \\
\text { obtained is reliable (X3.5) } \\
\text { Believe in the use of risk- } \\
\text { free digital technology } \\
\text { (X3.6) } \\
\text { Feel safe using digital } \\
\text { technology (X3.7) }\end{array}$ \\
\hline $\begin{array}{l}\text { Perceived Ease of } \\
\text { Use (X4) }\end{array}$ & $\begin{array}{l}\text { The extent to which one believes that the } \\
\text { use of certain system technologies will } \\
\text { provide convenience }\end{array}$ & $\begin{array}{l}\text { - } \quad \text { Learn to operate digital } \\
\text { technology easily (X4.1) } \\
\text { Easy to find information } \\
\text { about digital technology } \\
\text { (X4.2) } \\
\text { - Finding the user interface } \\
\text { clearly (X4.3) } \\
\text { Discovering that digital } \\
\text { technology is flexible } \\
(\mathrm{X} 4.4)\end{array}$ \\
\hline
\end{tabular}




\begin{tabular}{|c|c|c|}
\hline Variable & Definition & Indicator \\
\hline $\begin{array}{l}\text { Perceived } \\
\text { Usefulness (X5) }\end{array}$ & $\begin{array}{l}\text { The extent to which one believes } \\
\text { that digital technology is effective to } \\
\text { improve the efficiency of its work }\end{array}$ & $\begin{array}{ll}- & \text { Digital technology is easy } \\
\text { to use (X4.5) } \\
\text { The use of digital } \\
\text { technology will improve } \\
\text { working efficiency (X5.1) } \\
\text { - The use of digital } \\
\text { technology facilitates } \\
\text { business activities (X5.2) }\end{array}$ \\
\hline $\begin{array}{l}\text { Intention to Use } \\
(\mathrm{Y})\end{array}$ & $\begin{array}{l}\text { The possibility of users to use digital } \\
\text { technology }\end{array}$ & $\begin{array}{l}\text { The use of digital } \\
\text { technology makes } \\
\text { recording } \\
\text { transactions/books easier } \\
\text { (X5.3) } \\
\text { If you have access, intend } \\
\text { to use the } \\
\text { Because it has access, it } \\
\text { will still use } \\
\text { - I Will try to use }\end{array}$ \\
\hline
\end{tabular}

\section{Hypothesis:}

1. Context positively and significantly affects the Ease of Use of MSMEs digitization.

2. Context positively and significantly affects the Usefulness of MSMEs digitization.

3. Trust has a positive and significant impact on the Intention to Use the digitization of MSMEs.

4. Personal Initiatives and Characteristics positively and significantly influence the Intention to use the digitization of MSMEs.

5. Perceived Ease of Use has a positive and significant effect on the Intention to use digitalization of MSMEs

6. Perceived Usefulness has a positive and significant effect on the Intention to use the digitization of MSMEs

\section{Structural Equation Modelling}

To achieve the objectives of research and hypothesis submission, the data obtained is then processed according to the needs of the analysis using the Structural Equation Model (SEM). Structural Equation Modeling (SEM) is a multivariate analysis technique that combines the confirmatory factor analysis aspect and the tiered aspect of the simultaneous equation model. There are two steps in SEM modeling, namely: (1) measurement model that is testing the dimensions of a construct, (2) structural model that is testing the causality relationship between variables.

The analysis model proposed in this study can be seen in figure 2 .

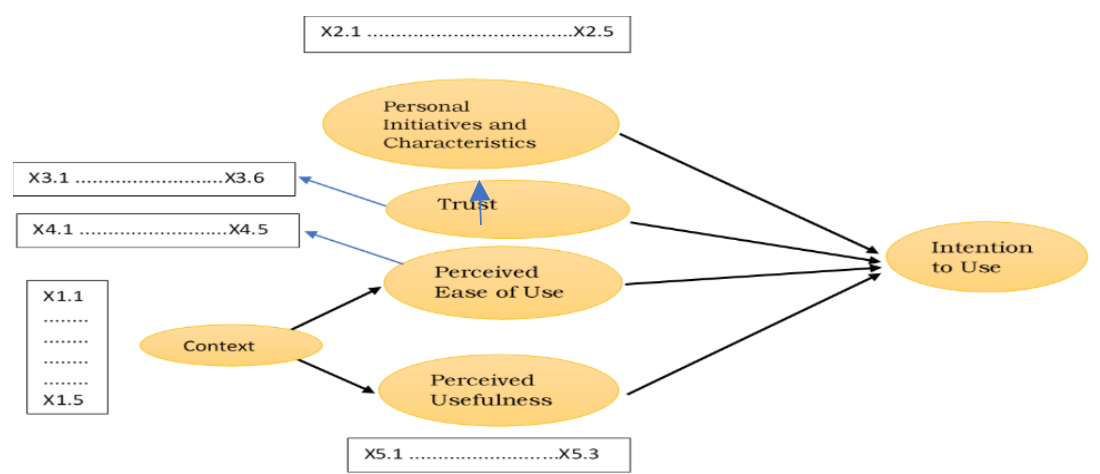

Figure 1. Research Structure Model 


\section{RESULT AND DISCUSSION}

\section{Measurement Model Evaluation (Outer ModeI)}

The evaluation of the measurement model includes three stages, namely convergent validity test, discriminant validity test, and composite reliability test. The convergent validity reflects the correlation between the indicator score and its construct score, which in the PLS model is stated valid if it has an outer loading value of $\geq 0.7$ and an AVE value $\geq$ of 0.5 (Jogiyanto, 2009). According to Chin (1998) in Ghozali (201), a correlation meets the validity of convergence if it has a loading value of more than 0.5 . This test aims to determine the validity of each relationship between an indicator and its latent variables. The convergent validity test of the 26 indicators used in this study has four declared invalid indicators: two indicators for personal initiative and character (PI) variables and two indicators on Trust variables. Furthermore, the four invalid indicators are removed from the model so that only 22 indicators will be processed.

Testing the validity of discriminant (discriminant validity) reflective indicators needs to be done by comparing the values in the cross-loading table. This test is used to ensure that the concept of each variable or has a unique value that only correlates with the indicators in the variable. An indicator is said to meet the validity of the discriminant if the cross-loading value of the indicator against its variable is the largest compared to other variables. The results of the discriminant validity test show that the construct has an adequate discriminant in the sense that all constructs have better discriminant validity than the indicators in the other blocks (Table 2).

Tabel 2. Discriminant Validity

\begin{tabular}{|c|c|c|c|c|c|c|}
\hline & Context & $\begin{array}{l}\text { Intention } \\
\text { to Use }\end{array}$ & $\begin{array}{l}\text { Perceived } \\
\text { Ease } \\
\text { of Use }\end{array}$ & $\begin{array}{l}\text { Perceived } \\
\text { Usefulness }\end{array}$ & $\begin{array}{c}\text { Personal } \\
\text { Initiatives- } \\
\text { Characteristic }\end{array}$ & Trust \\
\hline Context & 0,840 & & & & & \\
\hline Intention to Use & 0,651 & 0,940 & & & & \\
\hline Percieved Ease of Use & 0,568 & 0,776 & 0,861 & & & \\
\hline Percieved Usefulness & 0,712 & 0,787 & 0,722 & 0,912 & & \\
\hline $\begin{array}{l}\text { Personal Initiatives- } \\
\text { Chararteristic }\end{array}$ & 0,834 & 0,612 & 0,631 & 0,614 & 0,916 & \\
\hline Trust & 0,508 & 0,321 & 0,350 & 0,423 & 0,434 & 0,824 \\
\hline
\end{tabular}

Reliability testing of indicators is important because it explains how large an item is as an indicator of the measured construct. The test can be done with several approaches, namely Cronbach's alpha, correlated item-total correlation, Composite Reliability, and Average Variance Extracted (AVE. Cronbach's Alpha is a measure of reliability with values ranging from zero to one (Hair et al., 2010). A variable that includes several indicators is reliable if the minimum reliability level value of Cronbach's Alpha is 0.70 (Eisingerich and Rubera, 2010). If using correlated item-total correlation, an indicator is reliable if it has a correlation value of at least 0.50 (Hair et al., 2010). Meanwhile, if using a composite reliability approach is considered better in estimating the internal coexistence, the indicator is declared reliable if it has more than 0.6. By paying attention to these approaches (Table 3), consistently, the indicators on all variables studied are declared reliable.

Table 3. Construct Reliability and Validity

\begin{tabular}{lrrrr}
\hline & $\begin{array}{c}\text { Cronbach's } \\
\text { Alpha }\end{array}$ & rho_A & $\begin{array}{c}\text { Composite } \\
\text { Reliability }\end{array}$ & $\begin{array}{c}\text { Average Variance } \\
\text { Extracted (AVE) }\end{array}$ \\
\hline Contex & 0,898 & 0,920 & 0,923 & 0,706 \\
Intention to Use & 0,869 & 0,876 & 0,939 & 0,884 \\
Percieved Ease of Use & 0,881 & 0,903 & 0,919 & 0,741 \\
Percieved Usefulness & 0,900 & 0,917 & 0,937 & 0,832 \\
Personal Initiatives-Chararteristic & 0,904 & 0,913 & 0,940 & 0,840 \\
Trust & 0,883 & 0,906 & 0,913 & 0,679 \\
\hline
\end{tabular}

Source: Primary data, processed 


\section{Structural Model Evaluation (Inner Model)}

Evaluation of structural models in SEM with PLS is conducted by conducting R-squared tests and significance tests by estimating path coefficients. Table 4 presents R Square calculation results. The coefficient of determination or R-Square reflects how much a free variable affects dependent variables. The higher the coefficient of determination (R Square) indicates that the better the model, it also has the more precise predictive power. According to Chin (1998) in Ghozali (2013), the model is good if it has a coefficient of determination of at least 0.67 . Based on this idea, overall independent variables could explain the model variation as high as 71.6 percent $(0.716)$, which means in either category. Meanwhile, the Context variable only explains the variation of the Perceived Ease of Use variable by 32.3 percent and Perceived Usefulness by 50.7 percent.

Table 4. R-Square

\begin{tabular}{lrr}
\hline & R Square & R Square Adjusted \\
\hline Intention to Use & 0,716 & 0,694 \\
Perceived Ease of Use & 0,323 & 0,310 \\
Perceived Usefulness & 0,507 & 0,498 \\
\hline
\end{tabular}

Source: Primary data, processed

\section{Significance Tes}

The significance test is intended to identify a large number of independent variables affecting dependent variables. We are bootstrapping Calculation Results data Research using SEM PLS presented in table 5 shows that there are two other hypotheses, namely Trust has a positive and significant effect on the intention to use digitalization of MSMEs and Personal Initiatives and Characteristics has a positive and significant impact on the intention to use digitalization of MSMEs is not proven, with a t-test value smaller than 1.65581 or sig. $>0.05$.

Table 5. Path Coeficients

\begin{tabular}{|c|c|c|c|c|c|}
\hline & $\begin{array}{l}\text { Original } \\
\text { Sample }\end{array}$ & $\begin{array}{l}\text { Sample } \\
\text { Mean }\end{array}$ & $\begin{array}{l}\text { Standard } \\
\text { Deviation }\end{array}$ & $\begin{array}{c}\mathrm{T} \\
\text { Statistics }\end{array}$ & $\begin{array}{c}\mathrm{P} \\
\text { Values }\end{array}$ \\
\hline Ease of Use & 0,568 & 0,576 & 0,105 & 5,411 & 0,000 \\
\hline Contex -> Percieved Usefulness & 0,712 & 0,718 & 0,070 & 10,154 & 0,000 \\
\hline Percieved Ease of Use -> Intention to Use & 0,399 & 0,406 & 0,150 & 2,663 & 0,008 \\
\hline Percieved Usefulness -> Intention to Use & 0,460 & 0,466 & 0,167 & 2,752 & 0,006 \\
\hline $\begin{array}{l}\text { Personal Initiatives-Chararteristic } \quad-> \\
\text { Intention to Use }\end{array}$ & 0,104 & 0,097 & 0,197 & 0,525 & 0,600 \\
\hline Trust -> Intention to Use & $-0,059$ & $-0,047$ & 0,084 & 0,700 & 0,484 \\
\hline
\end{tabular}

Source: Primary data, processed

Four hypotheses are statistically supported. The four hypotheses are Context has a positive and significant effect on the Ease-of-Use digitizing MSMEs. Context has a positive and significant effect on the perceived usefulness of MSME digitization. Perceived Ease of Use has a positive and significant impact on the intention to use MSME digitization, and Perceived Usefulness has a positive and significant impact on intention to use the digitization of SMEs. This is reflected in the t-statistical value, which is greater than the t-table of 1.65581 , or the probability value of sig. 0.000 is less than the specified alpha of 0.05 .

Context has a positive and significant effect on Perceived Ease of Use and Perceived Usefulness. It means that there is a unidirectional change between Context and Perceived Ease of Use and Context with Perceived Usefulness. The use of digital technology by people around, pleasant experiences, ease of access, and a higher government drive will encourage the increased confidence to use certain system technologies will provide convenience to improve the efficiency of its work. Perceived Ease of Use has a positive and significant effect on the intention to use digitalization of MSMEs. It means that people believe that digital technology will provide convenience and that digital technology improves its working efficiency, the higher the intention to use digital technology. The digitalization of MSMEs is getting easier to implement. 


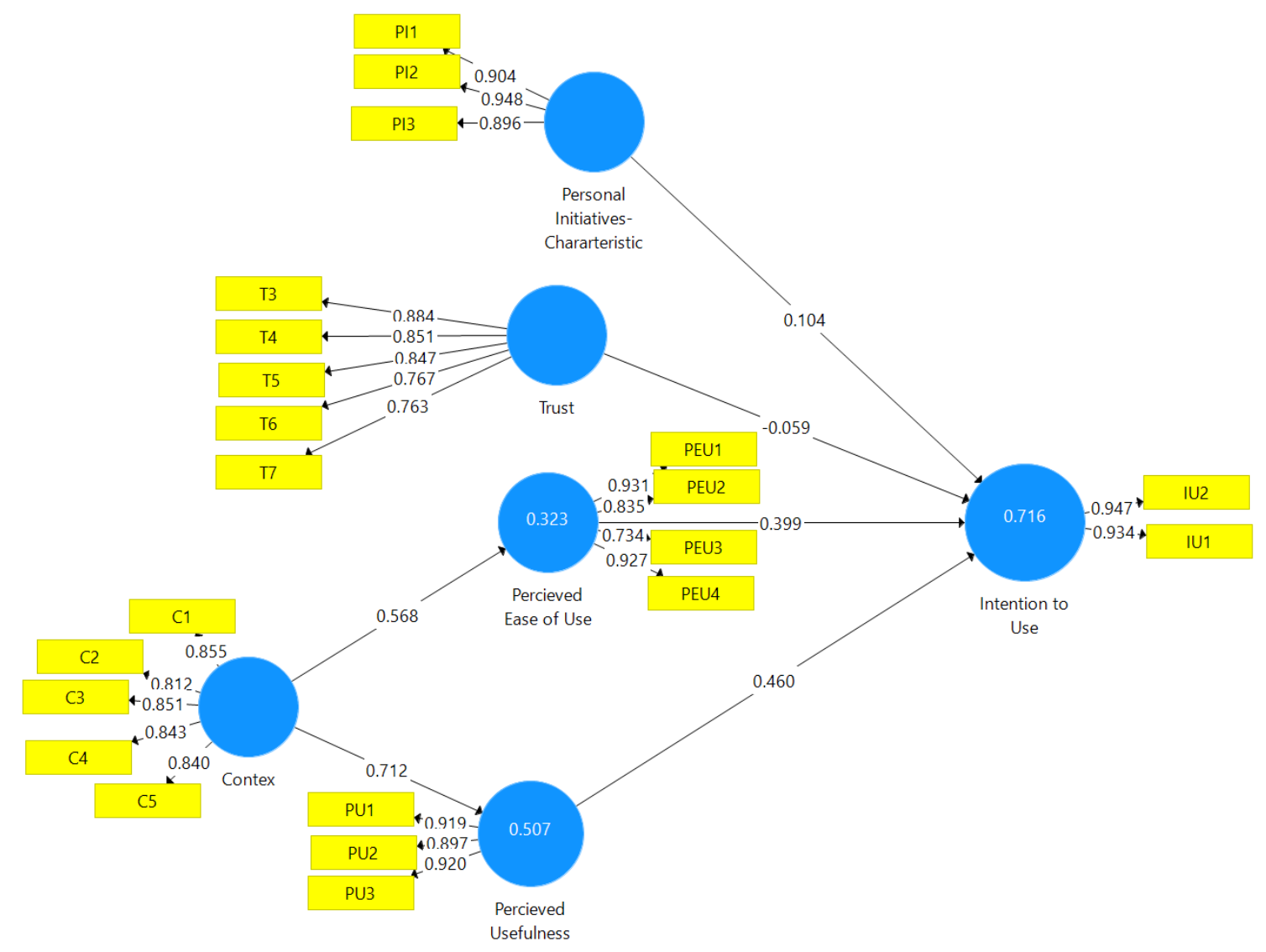

Figure 2. Structure Model (Path Coefficients Diagram)

Context has more effect on perceived Usefulness than it does on perceived Ease of Use, reflected in the regression coefficients of 0.712 and 0.568 . Perceived Ease of Use has more influence on the intention to use digitalization of MSMEs than Perceived Usefulness. The coefficient of each is positive and significant of 0.460 reflects that condition. Context indirectly affects the intention to use digitalization of MSMEs through its positive and significant influence on Perceived Ease of Use and Perceived Usefulness, respectively to P-Value 0.048 and 0.012 and a P-Value total of 0.000

Table 6. Indirect Effect

\begin{tabular}{lrrrr}
\hline & $\begin{array}{c}\text { Original } \\
\text { Sample }\end{array}$ & $\begin{array}{r}\text { Standard } \\
\text { Deviation }\end{array}$ & $\begin{array}{c}\text { T } \\
\text { Statistics }\end{array}$ & \multicolumn{1}{c}{$\begin{array}{c}\text { V } \\
\text { Values }\end{array}$} \\
\hline $\begin{array}{l}\text { Contex -> Percieved Ease of Use -> Intention to } \\
\text { Use }\end{array}$ & 0,227 & 0,114 & 1,986 & 0,048 \\
$\begin{array}{l}\text { Contex -> Percieved Usefulness -> Intention to } \\
\text { Use }\end{array}$ & 0,328 & 0,130 & 2,531 & 0,012 \\
Contex -> Intention to Use & 0,477 & 0,113 & 4,226 & 0,000 \\
\hline
\end{tabular}

Source: Primary data, processed

\section{Discussion}

Using the UTAUT tested by path analysis using the PLS 3.29 series shows that the model built meets the goodness of fit criteria. The convergent validity that reflects the correlation between the indicator score and its construct score was valid with the outer loading value of $\geq 0.7$ and an AVE value $\geq$ of 0.5 . The discriminant validity test that ensures that each variable has a unique value shows that the construct has an adequate discriminant in the sense that all constructs have better discriminant validity than the indicators in the other blocks. The composite reliability test that shows the reliability of indicators that tested by Cronbach's alpha, correlated item-total correlation, Composite Reliability, and Composite Reliability also shows consistently, the indicators on all 
variables studied are consistently reliable. It has Cronbach's Alpha $\geq 0,70$, a correlation value and Average Variance Extracted (AVE) $\geq 0.50$, and Composite Reliability $\geq 0.6$. Evaluation of structural models in SEM with PLS that reflected by the coefficient of determination shows that the model has an R-Square of 71.6 percent $(0.716)$. It means that aggregately the independent variables could explain the model variation quite high at 71.6 percent $(0.716)$. Meanwhile, the Context variable only explains the variation of the Perceived Ease of Use variable by 32.3 percent and Perceived Usefulness by 50.7 percent.

There are four hypotheses of UTAUT implemented on MSMEs that are statistically proven. The four hypotheses are Context has a positive and significant effect on the Ease-of-Use digitizing MSMEs. Context has a positive and significant effect on the perceived usefulness of MSME digitization. Perceived Ease of Use has a positive and significant impact on the intention to use MSME digitization, and Perceived Usefulness has a positive and significant impact on intention to use the digitization of SMEs. This is reflected in the t-statistical value, which is greater than the t-table of 1.65581 , or the probability value of sig. 0.000 is less than the specified alpha of 0.05 . This finding is a little bit different from the UTAUT model the be referred which shows that Personal InitiativesCharacteristics and Trust also have a positive significance toward intention to use. It is probably because of the differences in the character of the sample and desensitization. Desensitization is a gradual process that can affect a person's perspective. It may work in the case of intention to digitalize, especially in using financial technology (FinTech). How a person will behave can also be explained by the Stimulus, Organism, Response (SOR). SOR explains the influence of the physical environment on the internal state and individual behavior (Park, 2008). The stimulus affects the internal organism of an individual, which is reflected in its cognitive and affective aspects. Both are implemented by intermediaries and processes that mediate the relationship between stimulus and individual responses in purchasing behavior for organic food.

The knowledge possessed by individuals will determine attitudes and ultimately have implications for their behavior. According to The Theory of Reasoned Action, how a person will behave can be predicted from his behavioral intention. There are two variables for determining it, namely attitudes and subjective norms. If someone has a positive attitude towards an attitude object, then a high intention will appear if the social norms support this behavior. Attitudes towards something are influenced by the characteristics of the object of behavior and the evaluation of its benefits if someone behaves as he would do. If the individual feels the benefits directly, then he will build positive behavioral attitudes. The insignificant effect of the Trust and personal initiative and characteristics in this study is understandable. It is probably affected by culture. People tend to trust other people, such as public figures and the people surrounding them (family, close friends). People will believe in technology if other people are already using it.

\section{CONCLUSSION AND RECOMMENDATION}

Generally, the UTAUT test shows that the model works on Adopting Financial Technology (FinTech) by MSMEs. The Measurement Model Evaluation (Outer Model) and Structural Model Evaluation (Inner Model) reflect that the model work. However, regarding the factors that influence the behavior intention in using Fintech by MSMEs, it is different from previous research that became a reference. In the referenced model, Context has a significant positive effect on Perceived Ease of Use and Perceived Usefulness. Personal Initiatives and Characteristics, Trust, Perceived Ease of Use, and Perceived-Usefulness, have a significant positive effect on the intention to use fintech. In this study, there are four hypotheses proven. Those are Context had a significant positive effect on Perceived Ease of Use and Perceived Usefulness, and Perceived Ease of Use and Perceived Usefulness had a significant positive effect on the intention to use fintech.

Concerning efforts to realize financial inclusion as part of poverty alleviation efforts by improving MSMEs' competitiveness, the government needs to encourage the use of digital technology. The government can do providing training and guaranteeing ease of installation and access to digital technology. In addition, starting from the findings that perceived ease of use and perceived usefulness have a significant effect, decision-makers must show that the system technologies provide convenience and increase the effectiveness to improve the efficiency of its work. 


\section{REFERENCES}

Ajzen, I. (1991). Ajzen, I. (1991). The theory of planned behavior. Organizational Behavior and Human Decision Processes.The theory of planned behavior. In Organizational Behavior and Human Decision Processes.

Aryanto, V.D.W., Wismantoro, Y dan Widyatmoko, K. 2018. Implementing Eco-Innovation by Utilizing the Internet to Enhance Firm's Marketing Performance: Study of Green Batik Small and Medium Enterprises in Indonesia. International Journal of e-Business Research. 14(1). 21- 36.

Bappenas. (2020). Kajian Kebijakan Penanggulangan Dampak COVID-19 terhadap UMKM Survei Kebutuhan Pemulihan Usaha Bagi UMKM Indonesia. Bappenas.

Barua, A., Pinnel, J., \& Shutter. 2001. Measuring the Internet economy. Retrieved from http://ai.kaist. ac.kr/jkim/cs492a/internet_economy-UT.pdf.

Birkin, S. J., and Harris, M. L. 2003. E-Business and CRM: Directions for the Future. In Proceedings of the International Association for the Development of Information Systems (IADIS) Conference. Carvoeiro, Portugal, 5-8 November, pp. 121-8.

Blanchflower, D. G. (2000). Self-employment in OECD countries. Labour Economics. https://doi.org/10.1016/S0927-5371(00)00011-7

Bloch, M., Pigneur, Y., \&Sergev, A. 2006. On the road of electroniccommerce- a business value framework, gaining competitive advantage and some research issues. Laussane, Swizterland: University of Laussane.

Chia Cua, F., \& Garrett, T. C. (2010). Diffusion of Innovations Theory. In Handbook of Research on Contemporary Theoretical Models in Information Systems. https://doi.org/10.4018/978-160566-659-4.ch014

Eisingerich, A. B., \& Rubera, G. (2010). Drivers of Brand Commitment: A Cross-. National Investigation. Journal of International Marketing, 18(2), 64-79.Davis, F. D. (1989). Perceived usefulness, perceived ease of use, and user acceptance of information technology. MIS Quarterly: Management Information Systems. https://doi.org/10.2307/249008

Gao, S., Krogstie, J., \& Siau, K. (2011). Developing an instrument to measure the adoption of mobile services. Mobile Information Systems. https://doi.org/10.3233/MIS-2011-0110

Ghozali., I. 2013. Aplikasi Analisis Multivariate dengan Program IBM SPSS 19. Edisi 5. Penerbit Universitas Diponegoro: Semarang

Hair, Jr et.al. (2010). Multivariate Data Analysis (7th ed). United States : Pearson

Haltiwanger, J., \&Jarmin, R. S. 2000. Measuring the digital economy. Cambridge, MA: MIT Press.

Indonesia, K. K. R. (2020). Dirjen PPI: Survei Penetrasi Pengguna Internet di Indonesia Bagian Penting dari Transformasi Digital.

Jogiyanto, \& Abdillah, W. (2009). Konsep dan Aplikasi PLS (Partial Least Square) untuk Penelitian Empiris. Yogyakarta

Kementerian Keuangan. (2020). Program Pemulihan Ekonomi Nasional. Kementerian Keuangan.

Kenney, M., \& Curry, J. 2000. Beyond transac tion cost: E-commerce and the power of Internet dataspace. Berkeley, CA: University of California.

Kling, R., \& Lamb, R. 1999. IT and the organiza tional change in digital economies: A socio technical approach. Paper presented at the Conference on Understanding the Digital Economy: Data, Tools and Research, Washington, DC.

Masurel, E. (2007). Why SMEs invest in environmental measures: Sustainability evidence from small and medium-sized printing firms. Business Strategy and the Environment. https://doi.org/10.1002/bse.478

OECD. (2000). Korea and the Knowledge-based Economy: Making the Transition. World.

OECD. (2016). Automation and independent work in a digital economy. Policy Brief on the Future of Work.

Rogers, E. M., Singhal, A., \& Quinlan, M. M. (2019). Diffusion of innovations. In An Integrated Approach to Communication Theory and Research, Third Edition. https://doi.org/10.4324/9780203710753-35 Tapscott, D. 1998. The digital economy: Promise and peril in the age one worked intelligence. New York, NY: Mc-Graw Hill.

Wu, C. S., Cheng, F. F., Yen, D. C., \& Huang, Y. W. (2011). User acceptance of wireless technology in organizations: A comparison of alternative models. Computer Standards and Interfaces. https://doi.org/10.1016/j.csi.2010.03.002 
Yohan Wismantoro and MG Westri Kekalih Susilowati: How does Unified Theory of Acceptance and Use of Technology (UTAUT) Work on Adopting Financial Technology (FinTech) by MSMEs?

Zimmermann, H. D., \&Koerner, V. 2000. Management of customer relationship in the business media: The case of financial industry: New emerging industrial structures in the digital economy. Paper presented at the Conference on Information Systems, Milwaukee, WI.

Zysman, H., \& Weber, S. 2000. Governance and politics of the Internet economy: Historical transformation or ordinary politics with a new vocabulary? In International Encyclopedia of the Social \& Behavioral Sciences. Oxford, UK: Elsevier 